San Jose State University

SJSU ScholarWorks

Master's Theses

Master's Theses and Graduate Research

Fall 2016

\title{
Egg Turning Behavior and Egg Temperature in Relation to Mercury Contamination of Forster's Terns (Sterna forsteri)
}

Gregory T. Taylor

San Jose State University

Follow this and additional works at: https://scholarworks.sjsu.edu/etd_theses

\section{Recommended Citation}

Taylor, Gregory T., "Egg Turning Behavior and Egg Temperature in Relation to Mercury Contamination of Forster's Terns (Sterna forsteri)" (2016). Master's Theses. 4781.

DOI: https://doi.org/10.31979/etd.h5yy-k99x

https://scholarworks.sjsu.edu/etd_theses/4781

This Thesis is brought to you for free and open access by the Master's Theses and Graduate Research at SJSU ScholarWorks. It has been accepted for inclusion in Master's Theses by an authorized administrator of SJSU ScholarWorks. For more information, please contact scholarworks@sjsu.edu. 


\title{
EGG TURNING BEHAVIOR AND EGG TEMPERATURE IN RELATION TO MERCURY CONTAMINATION OF FORSTER'S TERNS (STERNA FORSTERI)
}

\author{
A Thesis \\ Presented to \\ The Faculty of the Department of Biological Sciences \\ San José State University
}

\author{
In Partial Fulfillment \\ of the Requirements for the Degree \\ Master of Science
}

by

Gregory T. Taylor

December 2016 
(C) 2016

Gregory T. Taylor

ALL RIGHTS RESERVED 
The Designated Thesis Committee Approves the Thesis Titled

EGG TURNING BEHAVIOR AND EGG TEMPERATURE IN RELATION TO

MERCURY CONTAMINATION OF FORSTER'S TERNS (STERNA FORSTERI)

by

Gregory T. Taylor

APPROVED FOR THE DEPARTMENT OF BIOLOGICAL SCIENCES

SAN JOSÉ STATE UNIVERSITY

December 2016

Scott A. Shaffer, Ph.D. Department of Biological Sciences

Joshua T. Ackerman, Ph.D. U. S. Geological Survey

Shelley L. Cargill, Ph.D. Department of Biological Sciences 


\begin{abstract}
EGG TURNING BEHAVIOR AND EGG TEMPERATURE IN RELATION TO MERCURY CONTAMINATION OF FORSTER'S TERNS (STERNA FORSTERI)

by Gregory T. Taylor
\end{abstract}

Several avian species exhibit reduced hatching success as a result of mercury contamination, but the mechanism by which this occurs is unknown. We examined egg turning rates and egg temperatures, two important determinants of egg hatchability, in relation to egg mercury contamination of Forster's terns (Sterna forsteri) in San Francisco Bay. Here, we used artificial eggs containing a data logger with a 3-D accelerometer, a magnetometer, and a temperature thermistor to monitor parental incubation behavior (sampled at $1 \mathrm{~Hz}$ ) of 186 tern nests. Overall, adults turned their eggs an average of $3.8 \pm 0.8 \mathrm{SD}$ turns $\mathrm{h}^{-1}$, which is nearly two times higher than that of other seabirds. Egg turning rates also increased with nest initiation date. Changes about the yaw axis (side-to-side egg movements) were the most prominent aspect of egg turning $\left(224 \pm 4.7\right.$ degrees $\left.h^{-1}\right)$, though roll and pitch (up-and-down movements) also showed substantial changes (149 \pm 2.5 degrees $\mathrm{h}^{-1}$ and $89 \pm 1.1$ degrees $\mathrm{h}^{-1}$, respectively). Despite the high variability in egg turning rates among individuals $\left(\mathrm{SD}=0.8\right.$ turns $\left.\mathrm{h}^{-1}\right)$, the rate of turning was not correlated with mercury concentrations in surrogate eggs collected from the same nest. Our results indicate that egg turning rates in Forster's terns are high, but unrelated to mercury contamination. 


\section{ACKNOWLEDGMENTS}

I would like to thank Scott Shaffer, for his guidance and advice every step of the way. Many thanks to Josh Ackerman, for his collaboration on this project and for sharing his expertise. Dr. Shelley Cargill, for her helpful feedback.

Thank you to Kim Sawyer, Crystal Shore, Jeannie Fasan, and Sam Lei for your help in the field. I am grateful to Dr. Cheryl Strong and the U. S. Fish and Wildlife Service for permission to conduct research at the Don Edwards San Francisco Bay National Wildlife Refuge.

I very much appreciate those who provided funding for this project, including the CSU COAST program, the Myers Oceanographic and Marine Biology Trust, the San Jose State University Department of Biological Sciences fellowships programs, and the USGS Western Ecological Research Center.

I would like to thank my labmates: Lindsey Broadus, Sue Cockerham, Jen Jelincic, and Brad Wilkinson, for their companionship. I thank my family for their support and encouragement. 


\section{TABLE OF CONTENTS}

List of Tables............................................................... vii

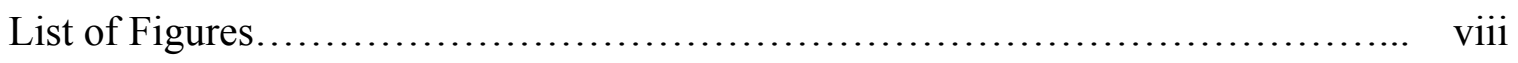

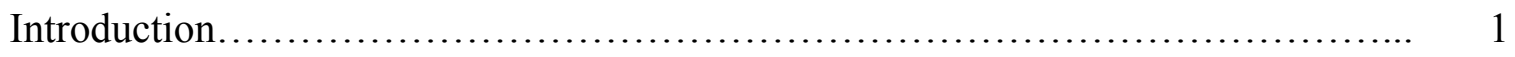

Methods and Materials........................................................... 3

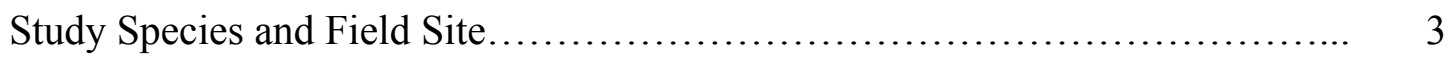

Egg Collection for Mercury Evaluation.................................... 3

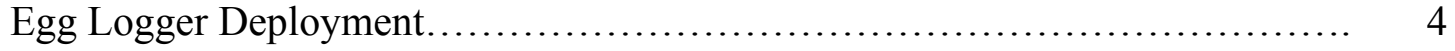

Egg Dissection and Processing............................................ 5

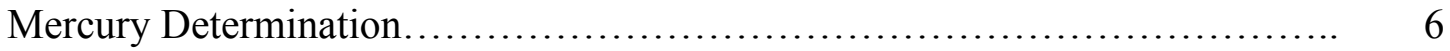

Data Processing ......................................................... 7

Statistical Analyses..................................................... 8

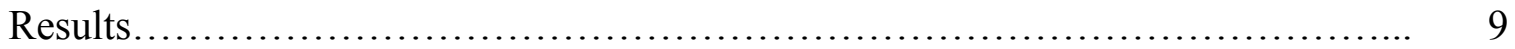

Mercury Contamination.............................................. 10

Egg Turning Behavior............................................... 10

Egg Temperature ....................................................... 11

Effects of THg on Egg Turning Rate.................................... 12

Effects of THg on Egg Temperature..................................... 14

Effects of Egg Turning Rate on Egg Temperature........................... 15

Discussion.................................................................. 16

Effects of Mercury on Incubation Behavior............................... 16

Egg Turning Rate in Forster's Terns.................................... 17

Changes in Egg Orientation.......................................... 21

Egg Temperature in Forster's Terns........................................ 23

Application.............................................................. 30

Future Directions....................................................... 31

Literature Cited................................................................... 32 


\section{LIST OF TABLES}

Table 1. Egg turning rates of Forster's terns, American avocets, and black-necked

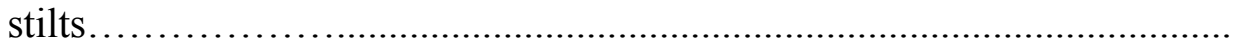

Table 2. Egg temperatures of Forster's terns, American avocets, and black-necked

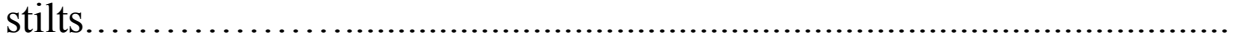




\section{LIST OF FIGURES}

Figure 1. A diagram illustrating the three aspects of egg orientation in Forster's terns: roll (red), pitch (black), and yaw (green).

Figure 2. Partial residual plots for each of the six explanatory variables in the egg turning rate model: (a) total mercury $\mathrm{THg}$, (b) incubation stage, (c) standardized nest initiation date, (d) clutch size, (e) hour of day, (f) day vs. night

Figure 3. Partial residual plots for each of the six explanatory variables in the egg temperature model: (a) total mercury $\mathrm{THg}$, (b) incubation stage, (c) standardized nest initiation date, (d) clutch size, (e) hour of day, (f) day vs. night

Figure 4. A partial residual plot for the number of hourly turns variable in the egg temperature model....

Figure 5. A boxplot showing the hourly number of turns during the night and during the day in terns......

Figure 6. A boxplot showing the hourly egg temperature during the night and during the day in terns.

Figure 7. A scatterplot showing the air temperature recorded by NOAA buoy RTYC1, located near colony R1...

Figure 8. A mixed line/bar plot showing 5 days of egg temperature (blue line) and egg turn rate (orange bars) from a tern nest. 


\section{Introduction}

Avian incubation involves a variety of parental behaviors that can affect the hatching success of eggs. One behavior, egg turning, plays a key role in ensuring proper embryonic development (Wilson et al., 2003; Hamburger and Openheim, 1967; Hutt, 1930; Robertson, 1961; Deeming, 2002). Egg turning facilitates the absorption of the albumen by the embryo (Deeming, 1991) and prevents the embryo from adhering to the shell membrane (New, 1957; Tona et al., 2005). Studies on domestic fowl have shown that failure to turn eggs can lower hatching rates by as much as $50 \%$ (Tullett and Deeming, 1987).

Environmental contaminants like mercury can also influence egg hatchability (Scheuhammer, 1987; Hoffman, 1990; Herring et al., 2010). However, the mechanism by which this toxin impairs egg hatching success is unknown. Previous research (Herring et al., 2010) suggested that mercury may depress or inhibit parental egg turning behavior, thereby reducing hatchability. Mercury is a known endocrine disruptor that interacts with prolactin (Tartu et al., 2015), testosterone (Jayasena, 2010), and corticosterone (Jayasena, 2010; Moore et al., 2014; Thaxton et al., 1982; Herring et al., 2012), all of which are strongly associated with incubation behavior (Ball, 1991; Van Roo et al., 2003; Goldsmith, 1991; Love et al., 2004). Although mercury has been shown to alter incubation behaviors (such as nest attendance) in a number of avian species, including Forster's terns (Evers et al., 2008; Eagles-Smith and Ackerman, 2010), specific behaviors like egg turning rates or patterns have not been examined simultaneously with measures of mercury contamination. Egg temperatures may also be affected by the egg turning 
behavior of the parents (Kelsey et al., 2016) or by decreased parental nest attendance. Thus mercury contamination may lead to suboptimal egg turning rates (Wilson et al., 2003; Robertson, 1961; Takeshita and McDaniel, 1982; Elibol and Brake, 2004) and abnormal egg temperatures (Molenaar et al., 2010; Byerly, 1938; French, 1994; French, 2000) that result in the malpositioning of an embryo, thereby preventing it from successfully hatching.

The San Francisco Bay, recognized as a wetland of international significance (Ramsar, 1971) and a site of hemispheric importance for shorebirds (Page et al., 1999), is a key stopover site along the Pacific Flyway (Stenzel et al., 2002) and serves as overwintering habitat for nearly 1 million waterbirds each year (Accurso, 1992). The Forster's tern is a piscivorous seabird that forages in the marshes and salt ponds along the perimeter of the Bay (Ackerman et al., 2008a), where mercury levels are particularly high (Marvin-DiPasquale et al., 2003). In fact, these birds exhibit the highest mercury concentrations of any bird in the San Francisco Bay (Ackerman et al., 2009; EaglesSmith et al., 2009). These high mercury levels have been shown to impair Forster's tern breeding productivity by increasing nest abandonment and decreasing egg hatchability (Eagles-Smith and Ackerman, 2010).

To evaluate whether mercury contamination negatively influences egg turning rates and egg temperature (resulting in lower hatching success), the egg attendance behavior of Forster's terns (Sterna forsteri) in the San Francisco Bay was studied. Egg mercury levels were used as a proxy for the mercury levels in the parents of a brood because previous research revealed that the two are strongly correlated in Forster's terns $\left(R^{2}=0.95\right.$ 
between mother and egg, and $R^{2}=0.84$ between father and egg; Ackerman et al., 2014; Ackerman et al., 2016). Furthermore, to expand our knowledge of egg turning behavior and egg temperatures in other bird species breeding in the same local habitat, data were collected on two additional species, black-necked stilts (Himantopus mexicanus) and American avocets (Recurvirostra americana). Two aspects of incubation behavior were examined: (1) the relationship between egg turning rate and egg temperature and (2) the relationship between egg turning rate and lay date. Forster's tern egg turning behavior was also compared with other species published elsewhere (Shaffer et al., 2014).

\section{Methods and Materials}

\section{Study Species and Field Site}

The incubation behavior and mercury contamination levels of Forster's terns (Sterna forsteri, hereafter “terns"), black-necked stilts (Himantopus mexicanus, hereafter "stilts"), and American avocets (Recurvirostra americana, hereafter "avocets") were studied at five colonies in the south San Francisco Bay, CA at the Don Edwards National Wildlife Refuge (Ponds AB1, AB2, A2W, R1, and New Chicago Marsh; 37² $26^{\prime} \mathrm{N}, 122^{\circ} 3^{\prime} \mathrm{W}$ ) from April-July 2015.

\section{Egg Collection for Mercury Evaluation}

One randomly selected egg was collected from a total of 186 tern nests, 19 stilt nests, and 8 avocet nests. Eggs were only collected from nests that contained at least two eggs, and only if all eggs in each nest were within 6-12 days of incubation initiation. Incubation stage was determined by floating eggs using methods described elsewhere (Westerskov, 1950; Ackerman and Eagles-Smith, 2010). Collected eggs were placed inside Whirl-Pak 
bags (Nasco, Fort Atkinson, WI) and carried in an egg carton that was kept in a cooler until they were transported and stored in a refrigerator at $4^{\circ} \mathrm{C}$. All eggs were collected under California Department of Fish and Wildlife and U.S. Fish and Wildlife Service Migratory Bird Permits and the San Jose State University Institutional Animal Care and Use Committee (SJSU 1022).

\section{Egg Logger Deployment}

After removing an egg for mercury assessment (described above), an artificial egg containing a data logger (see Shaffer et al., 2014 for details) with an onboard temperature thermistor, triaxial accelerometer and magnetometer, and a removable $4 \mathrm{~GB}$ microSD flash memory card was placed in the nest. At 1 second intervals, egg loggers recorded temperature (resolution $0.125^{\circ} \mathrm{C},<2^{\circ} \mathrm{C}$ accuracy) and 3-D orientation (resolution $1-2^{\circ}$ ). Each logger was positioned along the long axis of the egg in the center of each artificial egg, so all temperature measurements are considered core egg temperature.

All artificial eggs used for logger deployments were made by Advanced Assembly (Aurora, $\mathrm{CO}$ ) on a 3-D printer. Eggs were sized (45 mm length x $30 \mathrm{~mm}$ maximum breadth) to match the shape of Forster's tern eggs. Eggs were also filled with barium sulfate $\left(\mathrm{BaSO}_{4}\right)$, a non-toxic non-ferrous powder that does not affect the functioning of the sensors, to ensure the mass of the artificial eggs approximated that of a Forster's tern egg $(21.1 \pm 1.6 \mathrm{~g} \mathrm{SD})$. Printed eggs were then painted to match the color and pattern of tern eggs, using non-toxic water-based paint.

Potential biases due to changes in incubation behavior over the course of the incubation period (Beaulieu et al., 2010b; Clatterbuck et al., in review; Deeming, 2002) 
were reduced by deploying egg loggers in nests that were all 6-12 days into the incubation cycle. Incubation stage was also included as a covariate in the statistical models (described below). Egg loggers were left in each nest for one week, but data were logged (at $1 \mathrm{~Hz}$ ) for an average of $5.8 \pm 1.2 \mathrm{SD}$ days.

\section{Egg Dissection and Processing}

The length and breadth of each egg was measured to the nearest $0.01 \mathrm{~mm}$ using digital calipers (Fowler, Newton, MA), then weighed to the nearest $0.01 \mathrm{~g}$ using a digital balance (Ohaus Adventurer Pro, Ohaus Corporation, Pine Brook, NJ). A hole approximately $15-\mathrm{mm}$ in diameter was cut in the top of each egg using clean, stainless steel scissors. Egg contents were transferred to $60 \mathrm{~mL}$ vials using stainless steel forceps, then weighed with a digital scale to the nearest $0.01 \mathrm{~g}$. Egg contents were then frozen at $20^{\circ} \mathrm{C}$ until further analysis. Thawed egg contents were subsequently dried at $50^{\circ} \mathrm{C}$ for 48 h until completely dried, then reweighed to determine each egg's percent water content. Using a mortar and pestle, egg contents were homogenized to a powder.

\section{Mercury Determination}

Mercury analysis was conducted at the U.S. Geological Survey, Dixon Field Station Environmental Mercury Laboratory. Total mercury was used as an index of methyl mercury because $96 \%$ of the total mercury in bird eggs is in the methyl mercury form (Ackerman et al., 2013). Total mercury concentrations were determined on a Nippon MA-3000 Direct Mercury Analyzer (Nippon Instruments, College Station, Texas) following Environmental Protection Agency Method 7473 (U.S. Environmental Protection Agency, 2000), using an integrated sequence of drying, thermal 
decomposition, catalytic conversion, and then amalgamation, followed by atomic absorption spectroscopy. Total mercury (THg) concentrations in eggs were determined on a dry weight basis and then converted into a fresh wet weight egg concentration using egg-specific water content and egg morphometrics following the methods of Ackerman et al. (2013) and egg densities specific to these bird species (Herzog et al., 2016).

Quality assurance measures included analyses of two certified reference materials (either dogfish muscle tissue [DORM], dogfish liver [DOLT], or lobster hepatopancreas [TORT] certified by the National Research Council of Canada, Ottawa, Canada, or fish homogenate [IAEA] certified by the International Atomic Energy Agency), two system and method blanks, three continuing calibration verifications, and two duplicates per batch. Recoveries (mean \pm SE) for certified reference materials were $100 \% \pm 0.9 \%(\mathrm{n}=$ $45)$, and for calibration verifications were $99.8 \% \pm 0.2 \%(n=44)$. Absolute relative percent difference for duplicates averaged $2.8 \pm 0.4 \%(n=38)$.

\section{Data Processing}

All data analyses were conducted using custom routines created in MATLAB (The MathWorks, Natick, MA). Following methods of Shaffer et al. (2014), raw accelerometer and magnetometer measurements were converted to 3-2-1 Euler angles (yaw, pitch, and roll), to estimate instantaneous egg orientation. Roll orientation refers to the rotation of the egg about the long axis. To account for minor postural changes of a bird sitting on its eggs, only total orientation changes greater than $10^{\circ}$ were considered as an egg turning event. This threshold has also been used in similar studies (Beaulieu et al., 2010b; Thierry et al., 2013a; Shaffer et al., 2014), and it approximates the inflection point in the 
cumulative distribution between angle change and egg turning rate.

Because researcher presence in the colony (to survey and conduct egg deployments) lasted a maximum of two hours, and because terns generally returned to their nests very soon after researcher visits ( $<5 \mathrm{~min}$ ), all data within $2.5 \mathrm{~h}$ of egg logger deployment and recovery were excluded from the analysis.

Hourly and daily egg turning rates, as well as mean hourly and daily temperatures, were determined for each egg logger deployment, consistent with previous studies (Beaulieu et al., 2010b; Shaffer et al., 2014; Kelsey et al., 2016). Daily egg turning rate was characterized as the number of turns between consecutive sunrises. Sunrise and sunset times were determined from ephemeris tables using the latitude and longitude of colony A2W, which is centrally located among all the tern colonies.

\section{Statistical Analyses}

All mercury concentrations were natural log-transformed to improve normality, and are reported as micrograms per gram fresh wet weight $(\mu \mathrm{g} / \mathrm{g}$ fww). Paired t-tests were used to determine whether hourly egg turning rate differed between day and night. Multivariate regression models were used to 1) determine which explanatory variables were the most important predictors of hourly egg turning rate and hourly egg temperature, and 2) determine whether egg turning rate was an important predictor of egg temperature. Parameter estimation was conducted using Standard Least Squares.

For hourly egg turning rate and hourly egg temperature, the following explanatory variables were included as fixed effects: mercury concentration, incubation stage, standardized nest initiation date, clutch size, hour of day, and day vs. night (a categorical 
variable). Incubation stage was defined as the day of the incubation period (1-24 for Forster's terns). To standardize nest initiation date, the initiation date for each nest was first back-calculated based on the date in which the first egg in the nest hatched, using the average length of the incubation period for the species. Median nest initiation date for the species was determined and this was subtracted from each nest's initiation date. Clutch size was defined as the total number of eggs in a nest during egg logger deployment, and includes the egg logger itself. Hour of day (1-24) was converted to a circular statistic by first dividing the hour of day by 24 , then multiplying by $2 \pi$, and finally creating two separate variables from this by taking the sine for one and the cosine for the other; both of these variables were then included together in all models (Zar, 1999). A given hour was categorized as "day" if at least $50 \%$ of that hour occurred between sunrise and sunset; otherwise it was categorized as "night."

To determine whether hourly egg turning rate predicted hourly egg temperature, hourly egg turning rate, incubation stage, standardized nest initiation date, clutch size, hour of day, and day vs. night were included in models as fixed effects. In all models, a concatenated nest number + colony variable was included as a random effect. All statistical analyses were conducted using JMP (SAS Institute, Cary, NC), using a significance level of $p \leq 0.05$. All data are presented as mean \pm 1 SD unless otherwise stated.

\section{Results}

Of the 186 tern nests studied, insufficient data were collected from 37 nests for the following reasons: the egg logger was taken by a predator $(n=12)$, faulty batteries $(n=$ 
$9)$, or egg logger malfunction $(n=16)$. Eight percent $(n=15)$ of tern nests were abandoned during egg logger deployment, and the data from these nests were excluded from further analysis. Three nests also lacked mercury data due to the egg being cracked during transport. Therefore, a total of 131 tern nests yielded valid data for both mercury contamination and egg logger data. All further analyses presented are based on this sample size. Of the eight avocet nests studied, insufficient data were collected from two nests due to a malfunctioning egg logger and a predation event. Therefore only six avocet nests were analyzed for incubation behavior and mercury contamination. Viable data were obtained from all 19 of the stilt nests that were studied. Due to the small sample sizes for avocets and stilts, much of the following analyses were restricted to terns.

Mean clutch size was $2.4 \pm 0.5$ eggs in terns, $3.8 \pm 0.4$ in avocets, and $3.9 \pm 0.3$ in stilts.

\section{Mercury Contamination}

Mean THg concentration in tern eggs was $1.47 \pm 0.76 \mu \mathrm{g} / \mathrm{g}$ fww, and mean $( \pm \mathrm{SE})$ water content was $75.8 \pm 1.4 \%$. THg concentration did not vary by colony (ANOVA, $\mathrm{p}=$ $0.811)$ or clutch size $(\mathrm{p}=0.702)$. However, $\mathrm{THg}$ concentration increased linearly with standardized nest initiation date (LS linear regression, $\mathrm{p}=0.011, \mathrm{R}^{2}=0.049$ ).

Mean THg concentration in avocets eggs was $0.49 \pm 0.82 \mu \mathrm{g} / \mathrm{g}$ fww, and mean $( \pm$ SE) water content was $70.5 \pm 1.2 \%$. In stilt eggs, mean THg concentration was $0.67 \pm$ $0.36 \mu \mathrm{g} / \mathrm{g}$ fww, and mean $( \pm \mathrm{SE})$ water content was $70.0 \pm 2.4 \%$. 


\section{Egg Turning Behavior}

Mean hourly egg turning rate was highest in terns and lowest in stilts (Table 1). In all three species, hourly egg turning rates were significantly higher during the day than at night (paired t-test, $\mathrm{p}<0.001$ ), and were also more variable during the day (O'Brien test, $\mathrm{p}<0.001)$

\section{Table 1}

Egg turning rates of Forster's terns, American avocets, and black-necked stilts

\begin{tabular}{llll}
\hline Species & $\begin{array}{l}\text { Mean Hourly } \\
\text { Turn Rate }\end{array}$ & $\begin{array}{l}\text { Daytime Hourly } \\
\text { Turn Rate }\end{array}$ & $\begin{array}{l}\text { Nighttime Hourly } \\
\text { Turn Rate }\end{array}$ \\
\hline & & & \\
Forster's tern & $3.8 \pm 0.8$ & $4.5 \pm 1.1$ & $2.8 \pm 0.9$ \\
American avocet & $1.9 \pm 0.5$ & $2.2 \pm 0.6$ & $1.5 \pm 0.6$ \\
Black-necked stilt & $1.2 \pm 0.5$ & $1.5 \pm 0.6$ & $0.9 \pm 0.6$ \\
\hline
\end{tabular}

In all tern nests, the axis of orientation that showed the greatest amount of change in each egg turning event was the yaw, followed by the roll, then the pitch (Figure 1). For each egg turning event, the mean amount of angle-change was $59.0 \pm 1.2 \mathrm{deg}$ for the yaw axis, $39.3 \pm 0.6 \mathrm{deg}$ for the roll axis, and $23.4 \pm 0.3 \mathrm{deg}$ for the pitch axis. The overall mean angle-change per egg turning event was $46.3 \pm 0.5 \mathrm{deg}$. 


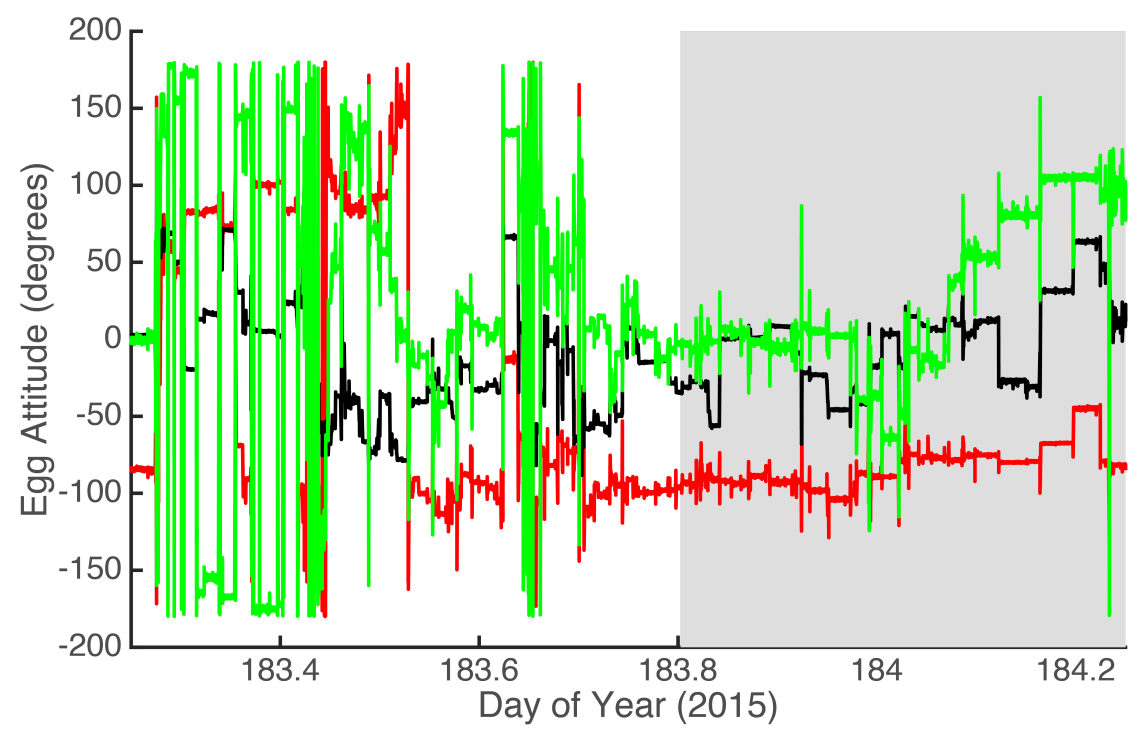

Figure 1. A diagram illustrating the three aspects of egg orientation in Forsters terns: roll (red), pitch (black), and yaw (green). Note the large change in yaw angle change relative to roll and pitch, as well as the difference in egg turning activity between night and day.

The angle-change per egg turning event was not correlated with hourly egg turning rate (LS linear regression, $p=0.165)$, daily egg turning rate $(p=0.085)$, daytime hourly egg turning rate $(\mathrm{p}=0.660)$, nighttime hourly egg turning rate $(\mathrm{p}=0.937)$, daytime egg temperature $(p=0.632)$, nighttime egg temperature $(p=0.679)$, standardized nest initiation date $(\mathrm{p}=0.158), \operatorname{THg}(\mathrm{p}=0.902)$, incubation stage $(\mathrm{p}=0.562)$, clutch size $(\mathrm{p}=$ 0.309), or colony (ANOVA, $\mathrm{p}=0.419$ ). Mean angle-change was therefore excluded from further analyses.

\section{Egg Temperature}

Mean daytime egg temperature was highest in terns and lowest in stilts (Table 2), and mean nighttime egg temperature followed this pattern as well. In all three species, the difference between daytime and nighttime temperatures was statistically significant 
(paired t-test, $\mathrm{p}<0.001$ ). In terns and stilts, hourly daytime egg temperatures were also more variable than hourly nighttime egg temperatures (O'Brien test, $\mathrm{p}=0.028$ and $\mathrm{p}<$ 0.001, respectively). The mean egg temperature range ( $\max -\min$ ) was similar between avocets and stilts, both of which had a larger mean egg temperature range than terns.

\section{Table 2}

Egg temperatures of Forster's terns, American avocets, and black-necked stilts.

Temperature range was defined as the difference between the maximum and the minimum egg temperature

\begin{tabular}{llll}
\hline Species & Egg Temperature $\left({ }^{\circ} \mathrm{C}\right)$ & \\
\hline & Daytime Mean & Nighttime Mean & Range \\
\hline Forster's tern & $40.0 \pm 2.5$ & $38.9 \pm 2.4$ & $10.8 \pm 4.5$ \\
American avocet & $38.9 \pm 2.3$ & $38.2 \pm 0.1$ & $12.3 \pm 5.4$ \\
Black-necked stilt & $38.4 \pm 1.8$ & $37.2 \pm 1.7$ & $12.2 \pm 4.6$ \\
\hline
\end{tabular}

\section{Effects of THg on Egg Turning Rate}

Of the six explanatory variables included in the multivariate regression model for hourly egg turning rate in Forster's terns, only two were not significant predictors: THg $(p=0.780)$ and incubation stage $(p=0.758)$. Whereas, clutch size $(p=0.033)$, hour of day $(\mathrm{p}<0.001)$, and day vs. night $(\mathrm{p}<0.001)$ showed negative relationships to hourly egg turning rate. Standardized nest initiation day showed a positive relationship with 
hourly egg turning rate $(\mathrm{p}<0.001$, Figure 2$)$.
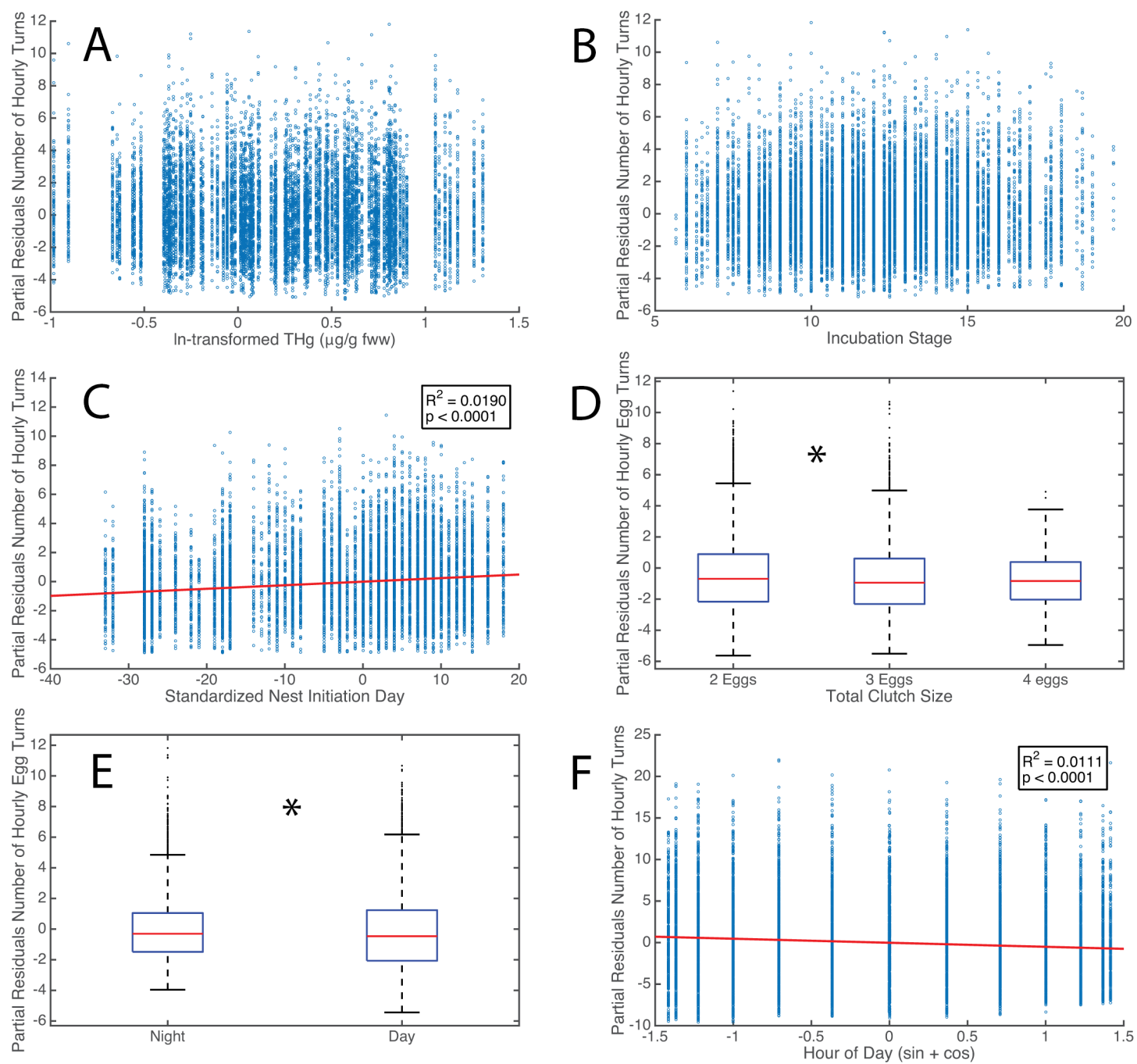

Figure 2. Partial residual plots for each of the six explanatory variables in the egg turning rate model: (a) total mercury $\mathrm{THg}$, (b) incubation stage, (c) standardized nest initiation date, (d) clutch size, (e) hour of day, (f) day vs. night. Asterisks denote a significant difference between groups. Standardized nest initiation date was defined as the difference between the initiation date of a given nest and the mean nest initiation date of the tern colony.

\section{Effects of THg on Egg Temperature}

Of the six explanatory variables included in the multivariate regression model for hourly egg temperature in Forster's terns, only two were not significant predictors: THg 
$(p=0.084)$ and clutch size $(p=0.921)$. Hour of day showed a negative relationship with hourly egg temperature $(\mathrm{p}<0.001)$. Incubation stage $(\mathrm{p}<0.001)$, day vs. night $(\mathrm{p}<$ $0.001)$, and standardized nest initiation day $(\mathrm{p}<0.001)$ all showed positive relationships with hourly egg temperature (Figure 3).
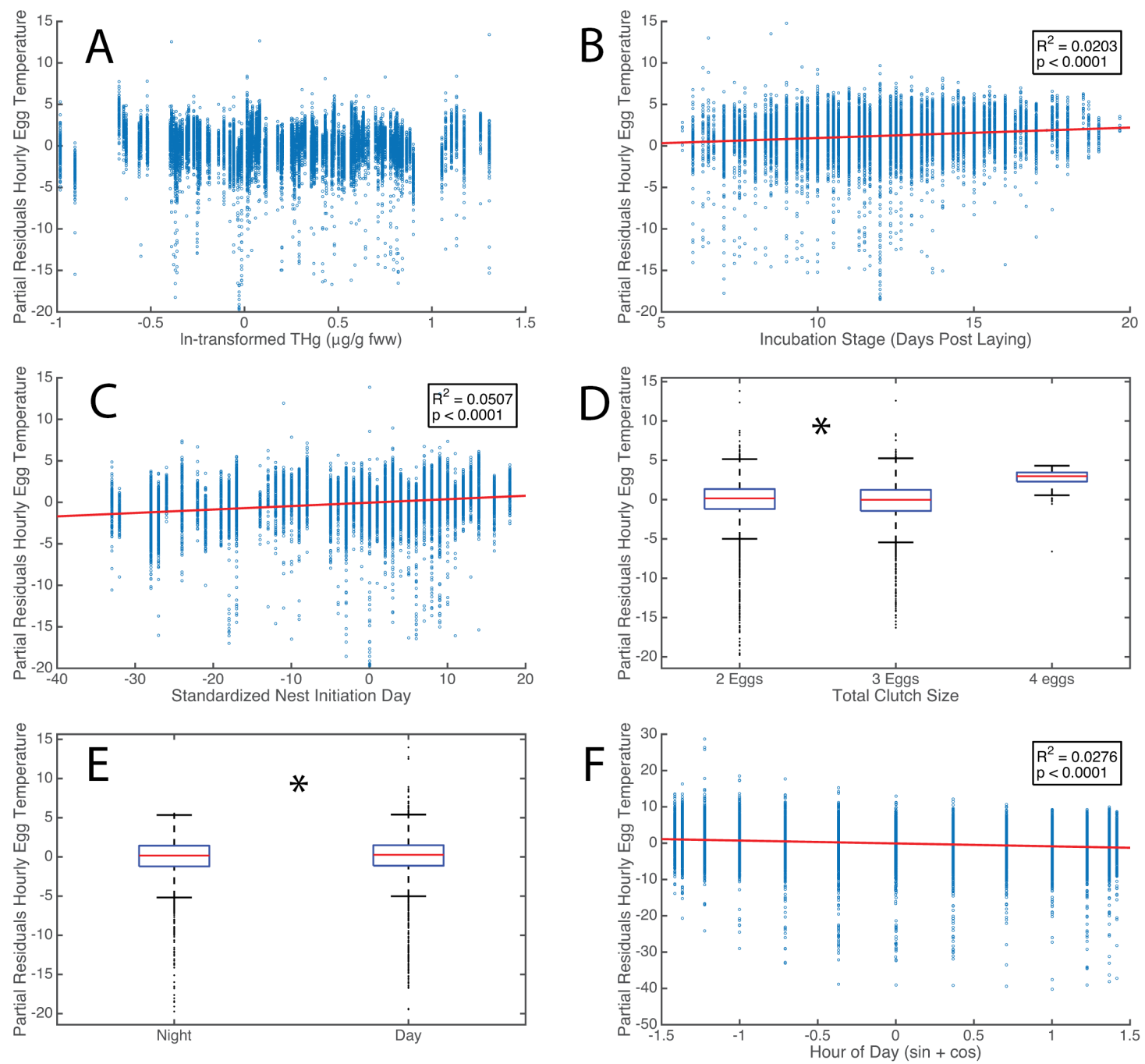

Figure 3. Partial residual plots for each of the six explanatory variables in the egg temperature model: (a) total mercury $\mathrm{THg}$, (b) incubation stage, (c) standardized nest initiation date, (d) clutch size, (e) hour of day, (f) day vs. night. Asterisks denote a significant difference between groups. 


\section{Effects of Egg turning Rate on Egg Temperature}

In this multivariate regression model, $\mathrm{THg}$ was replaced with hourly egg turning rate as an explanatory variable. Of the six explanatory variables included in this model, only clutch size was not a significant predictor of hourly egg temperature in Forster's terns ( $p$ $=0.982)$. Hour of day showed a negative relationship with hourly egg temperature $(\mathrm{p}<$ 0.001). Hourly egg turning rate $(\mathrm{p}<0.001)$, incubation stage $(\mathrm{p}<0.001)$, day vs. night ( $\mathrm{p}$ $<0.001)$, and standardized nest initiation day $(\mathrm{p}<0.001)$ all showed positive relationships with hourly egg temperature (Figure 4).

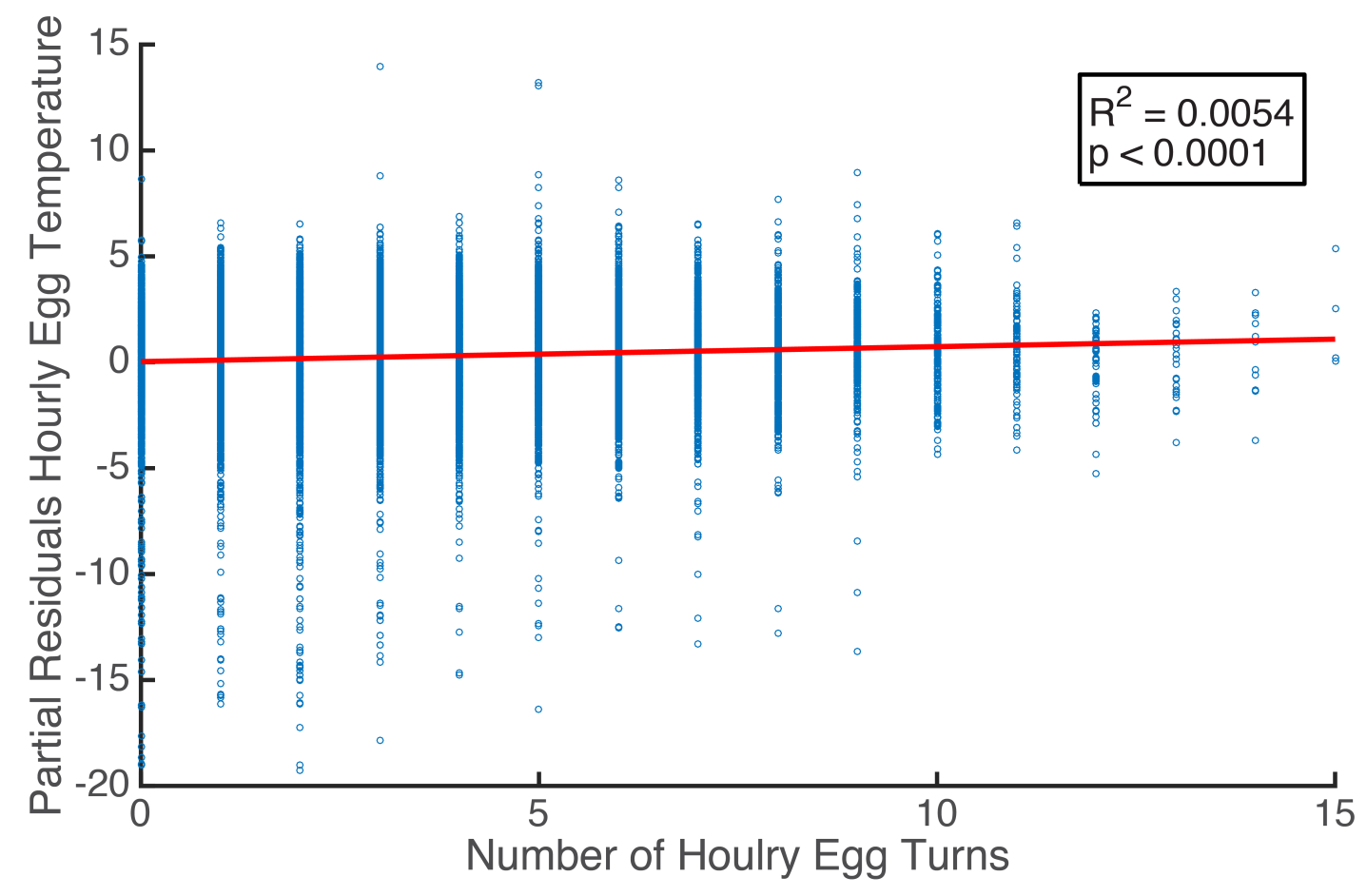

Figure 4. A partial residual plot for the number of hourly turns variable in the egg temperature model. 


\section{Discussion}

Neither egg turning rate nor egg temperature were correlated with mercury concentration, indicating that mercury lowers egg hatchability through some other mechanism. However, egg turning rate in Forster's terns was found to be considerably higher than that of other seabirds. The mean angle change per egg turning event was also higher than what has been found in any other bird. Furthermore, it was observed that egg turning rate increases with standardized nest initiation date.

Forster's tern egg temperature was positively correlated with standardized nest initiation date and egg turning rate. Egg temperature range in Forster's terns was higher than what has been found in most seabirds.

\section{Effects of Mercury on Incubation Behavior}

THg concentrations in Forster's tern eggs reflected a similar pattern to what has previously been measured in this population (Ackerman et al., 2016), and these levels have been shown to reduce egg hatchability (Ackerman et al., 2014). However, THg was not a significant predictor of egg turning rate or egg temperature in this study. One potential explanation for this result is that its effect only manifests in the first several days of the incubation period; only the middle portion of the incubation period was studied in this investigation. Egg turning during the early stages of incubation is critical for embryonic development (Card, 1926; New, 1957; Deeming, 1989) and the hormonal state of parents, which is in flux at the onset of incubation (Vleck, 1998; Vleck, 2002; Angelier and Chastel, 2009), is profoundly influential. Prolactin (Tartu et al., 2015), corticosterone (Evers et al., 2004; Jayasena, 2010), and testosterone (Heath and 
Frederick, 2005; Tartu et al., 2013) have all been shown to be affected by mercury, and the complex interactions among them at the start of incubation may be susceptible to its endocrine-disrupting effects. A second possibility is that there truly is no effect of $\mathrm{THg}$ on egg turning behavior in Forster's terns but that mercury decreases hatchability through some other mechanism, perhaps by impairing the neurological development of the embryo, as has been suggested by research on the domestic fowl (Gallus domesticus, Carvalho et al., 2008). Such impairment may prevent the chick from properly orienting itself within the egg in preparation for hatching. These results thus point toward multiple avenues of future research concerning mercury's effects on hatchability.

\section{Egg Turning Rate in Forster's Terns}

The present study is the first to examine egg turning rates in terns. Overall, Forster's terns had a mean egg turning rate of $3.8 \pm 0.8$ turns $\mathrm{h}^{-1}$, which is nearly twice the rate for other seabird species (but see Thierry et al., 2013b). Most species studied using similar technology average approximately 2 turns $\mathrm{h}^{-1}$ (Clatterbuck et al., in review; Kelsey et al., 2016; Shaffer et al., 2014), which is typical of birds with semi-precocial offspring (Deeming, 2002). Egg turning rates have been reported for several gull species (Carey, 1980), but these studies included numerous potential sources of inaccuracy (human disturbance, sampling only during the day, reliance on visual observations, small sample size, etc.) and only western gulls (Larus occidentalis) have been studied in detail (Shaffer et al., 2014). Three studies conducted on Adélie penguins (Pygoscelis adeliae) it was found that egg turning rates varied from 1.4 and 3.2 times per hour (Beaulieu et al., 2010b; Thierry et al., 2013a; Thierry et al., 2013b), though these loggers only had a bi- 
axial accelerometer and lacked a magnetometer. Incorporating a magnetometer has been shown to record $10-30 \%$ more turning events (Shaffer et al., 2014); thus, egg turning rates of Adélie penguins are likely to be higher. It is unclear why egg turning rates would be higher in this penguin species but perhaps future studies on other penguins will provide greater clarity.

One characteristic that differentiates all previous species from Forster's terns, and that may explain the difference in turning rates, is the duration of their foraging bouts. Forster's terns in the south San Francisco Bay generally forage within $1 \mathrm{~km}$ of their nests during the incubation period (Bluso-Demers et al., 2008), so they commonly conduct foraging excursions that are less than 1 hour (Fraser, 1997). Consequently, parents exchange incubation duties multiple times over the course of a day. In comparison, western gulls spend 2-4 hours away from the nest per foraging trip during the incubation period (Pierotti, 1981; Shaffer et al., submitted). Cassin's auklets exchange incubation duties on a nightly basis (i.e., ca. 24 hours), where parents alternate between foraging at sea at night or sitting on the nest and incubating the egg during the day (Kelsey et al., 2016). Both Adelie penguins and Laysan albatrosses alternate prolonged incubation bouts with long foraging trips so parents change out less frequently (Beaulieu et al., 2010a; Shaffer et al, 2014). Hence the high rate of egg turning in Forster's terns may be explained by more frequent turnover between parents in comparison to other seabird species.

A second behavioral aspect that is common in terns is their propensity to mob predators (McNicholl, 1971). Similar to the effects of frequent turnover between parents 
of the same nest, mobbing behavior in Forster's terns could also increase the number of egg movements when adults flush off and resettle back on the nest. Crows and gulls are commonly seen at the colonies that were studied. Although the quantification of the frequency of visits to these colonies was not quantified, several tern nests (including 12 with egg loggers) were predated during the study period, thus confirming the presence of predators in these colonies.

A third trait that differentiates terns from the aforementioned species is the high proportion of albumen in the egg. Although the relative fraction of albumen has not been measured in Forster's terns, the eggs of the closely related Common tern (Sterna hirundo) are composed of $67.5 \%$ albumen (Nisbet, 1978). In contrast, the eggs are $61.0 \%$ albumen in Cassin's auklets (Astheimer, 1986), 60.4\% in herring gulls (Larus argentatus; Meathrel et al., 1987), 61.6\% in Laysan albatrosses (Warham, 1983), and 65.0\% in Adélie penguins (Astheimer and Grau, 1985). Higher egg turning rates have been shown to improve the embryo's utilization of the albumen (Deeming, 1991); thus, a higher percentage of albumen in the egg may necessitate a higher egg turning rate, as suggested by Deeming (2002). This relationship has been found in a wide range of bird species (Deeming, 2002), and the findings of this study add further support for that theory.

Hourly egg turning rates in Forster's terns were 60\% higher during the day $(4.5 \pm 1.1$ turns $\left.\mathrm{h}^{-1}\right)$ than at night $\left(2.8 \pm 0.9\right.$ turns $\mathrm{h}^{-1}$, Figure 5). The higher daytime turning rate may be explained by the foraging behavior of the parents. As mentioned previously, parents exchange incubation duties several times throughout the day, whereas at night, both parents are generally present, and foraging trips are much less frequent (Bluso- 
Demers et al., 2010). Egg turning rates in western gulls also differ between day and night (Clatterbuck et al., in review), likely for similar reasons. Western gulls forage during the day, exchanging incubation duties multiple times, while at night they are more quiescent (Pierotti, 1981). This pattern is also evident, but reversed, in the nocturnal Cassin's auklet where egg turning rates are higher at night, when the parents are exchanging incubation duties (Kelsey et al., 2016, Shaffer et al., 2014). Laysan albatrosses do not exhibit diurnal patterns in egg turning rate (Shaffer et al., 2014), possibly because the exchange of incubation duties does not cycle diurnally in this species (Rice and Kenyon, 1962). Adélie penguins do exhibit diurnal cycles in restlessness (Derksen, 1977), but no study has specifically investigated whether egg turning rates vary diurnally in this species.

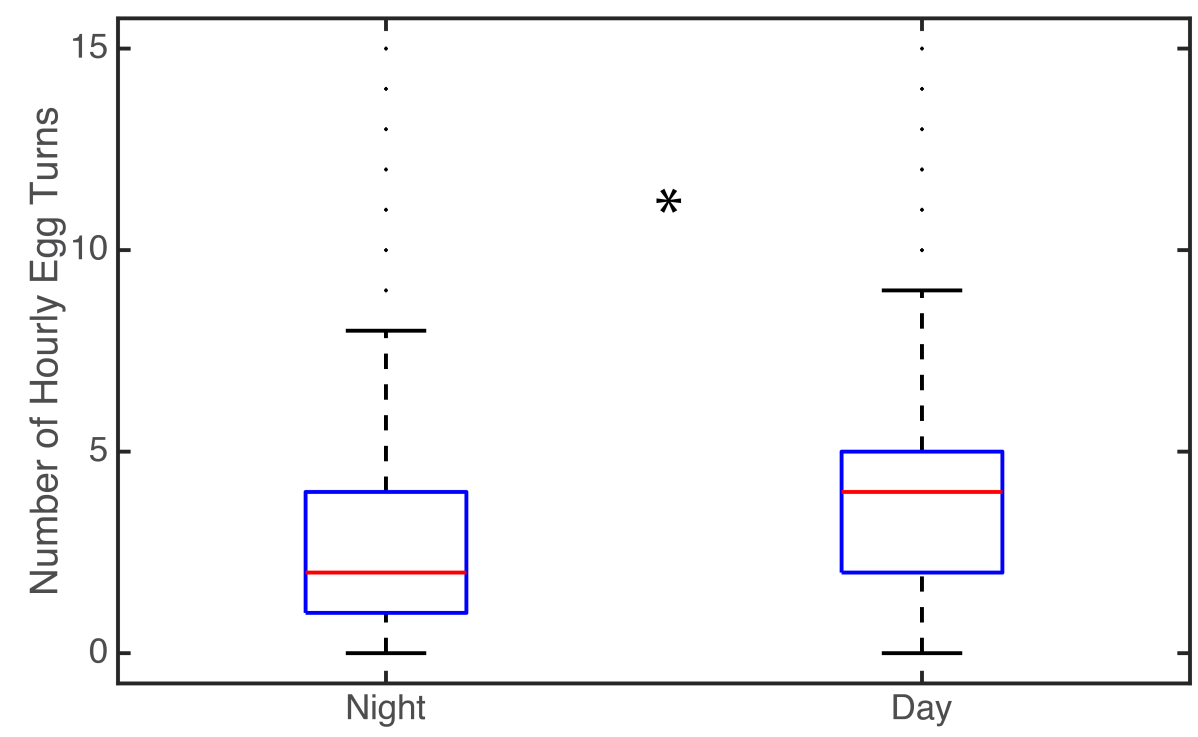

Figure 5. A boxplot showing the hourly number of turns during the night and during the day in terns. The boxes denote the median, $25 \& 75 \%$ quartiles, the range of data, and outliers.

The higher daytime egg turning rate in Forster's terns could also be a result of “dipping", a behavior exhibited during the hottest part of the day (Grant, 1982). This 
involves flying from the nest and dipping the beak, feet, and breast feathers into the water before quickly returning to the nest, which helps parents regulate the temperature of their eggs using evaporative cooling to prevent overheating (Grant, 1982; Dinsmore, 1970). Dipping has been observed in Forster's terns nesting on the Salton Sea in southern California (Grant, 1982), but has not been reported at colonies in the San Francisco Bay.

\section{Changes in Egg Orientation}

The axis of orientation that showed the greatest change during egg turning was the yaw attitude, followed by the roll, then the pitch. The same data loggers have been used in studies of Cassin's auklets, Laysan albatrosses, and western gulls and these species exhibit the same pattern (Shaffer et al., 2014). Thus, when a bird sits down on the nest, it shifts its eggs so that they match the arrangement of its brood patches. Rotating the egg along the yaw axis is the easiest method of doing so, as observed in herring gulls (Drent, 1970) and black-headed gulls (Beer, 1961). Conversely, in species with large clutch sizes and a single large brood patch, such as waterfowl, incubating adults do not need to manipulate each egg to individually fit into a brood patch. Rather, eggs are regularly rotated between the center and the periphery of the nest in order to maintain adequate egg temperatures (Boulton and Cassey, 2012). Waterfowl perform egg movements using their bill to shift eggs around the nest (Caldwell and Cornwell, 1975). Egg loggers with triaxial accelerometers have not yet been used to study egg movements in waterfowl, but it is likely that changes in the yaw axis will be smaller relative to roll and pitch during egg turning events. 
Overall mean angle-change per egg turning event in Forster's terns was $46.3 \pm 0.5$ deg. At a rate of 3.8 turns $\mathrm{h}^{-1}$, this equates to a mean angle-change of $176 \pm 1.8 \mathrm{deg} \mathrm{h}^{-1}$, which is greater than that of any species studied to date (Deeming, 2002). This study is the first study to report individual yaw, roll, and pitch components of the average egg turning event, for any bird. The absence of a relationship between the size of the angle change and clutch size, incubation stage, or nest initiation date indicates that this aspect of incubation is highly conserved in Forster's terns and is likely important in ensuring proper development of the embryo. Interestingly, 45 deg per egg-turn has been found to be the optimal turning angle for poultry (Funk and Forward, 1953; Funk and Forward, 1960), and is the standard angle change for artificial incubators (Kasielke et al., 2007). However, artificial incubators typically operate at just 1 turn per hour (Deeming, 2009). Incubation stage was not a significant predictor of egg turning rate. This was also found to be true for Adélie penguins (Thierry et al., 2013a; Thierry et al., 2013b; but see Beaulieu et al., 2010b) as well as Laysan albatrosses and western gulls (Clatterbuck, et al., in review). However, none of these species' egg turning behavior has been studied over the complete duration of the incubation period. This study sampled the middle half (days 6-18) of the 24-day incubation period for Forster's terns (Bergman et al., 1970; Hall, 1989), whereas studies on Adélie penguins sampled only the first one-third (days 113) of the 34-day incubation period (Ainley, 2002). The study conducted on western gulls and Laysan albatrosses also did not sample the first or last several days of incubation (Clatterbuck et al., in review). It is therefore not possible, based on these studies, to unequivocally determine whether egg turning rate changes over the full course of an 
incubation cycle in seabirds. Although several previous studies on terrestrial birds followed egg turning rate throughout the entire incubation period, the results were equivocal (Weaver and West, 1943; Weller, 1961; Valanne, 1966; Pulliainen, 1978; Howey et al., 1984). Therefore, more research using the latest technology is needed to fully illuminate this question.

Hourly egg turning rate showed a positive relationship with standardized nest initiation date. In other words, terns that began breeding early had lower hourly turning rates compared to terns that started later. It seems plausible that less-experienced adults nest later in the summer than more-experienced adults, as occurs in Common terns (Ludwigs and Becker, 2002). Less-experienced adults may be more restless and turn their eggs more frequently than more-experienced adults; unfortunately, the relationship between breeding experience and egg turning rate has not yet been investigated.

\section{Egg Temperature in Forster's Terns}

Mean egg temperature in Forster's terns was $40.0 \pm 2.5^{\circ} \mathrm{C}$ during the day and $38.9 \pm$ $2.4{ }^{\circ} \mathrm{C}$ at night. This is similar to results for other Larids, including western gulls, which range between 40.2 and $38.2{ }^{\circ} \mathrm{C}$ (Shaffer et al., 2014). This similarity is likely a result of similarities in brood patch temperature. Brood patch temperatures have not been measured in Forster's terns, though sooty terns (Onchoprion fuscatus) have a brood patch temperature of $39.6{ }^{\circ} \mathrm{C}$ (Howell and Bartholomew, 1962b). Brood patch temperatures of western gulls have likewise not been measured, but those of herring gulls average $40.5^{\circ} \mathrm{C}$ (Drent, 1970). 
Hour of day was a significant predictor of egg temperature in Forster's terns, which were on average $1.0^{\circ} \mathrm{C}$ higher during the day than at night (Figure 6). A likely explanation for this fluctuation in egg temperature is the circadian rhythm of parental body temperature. A number of seabirds exhibit daily changes in body temperature of 1-2 ${ }^{\circ} \mathrm{C}$ during the incubation period (Howell and Bartholomew, 1962a; Howell and Bartholomew, 1961a; Howell and Bartholomew, 1961b), though this has not been specifically measured in any tern species.

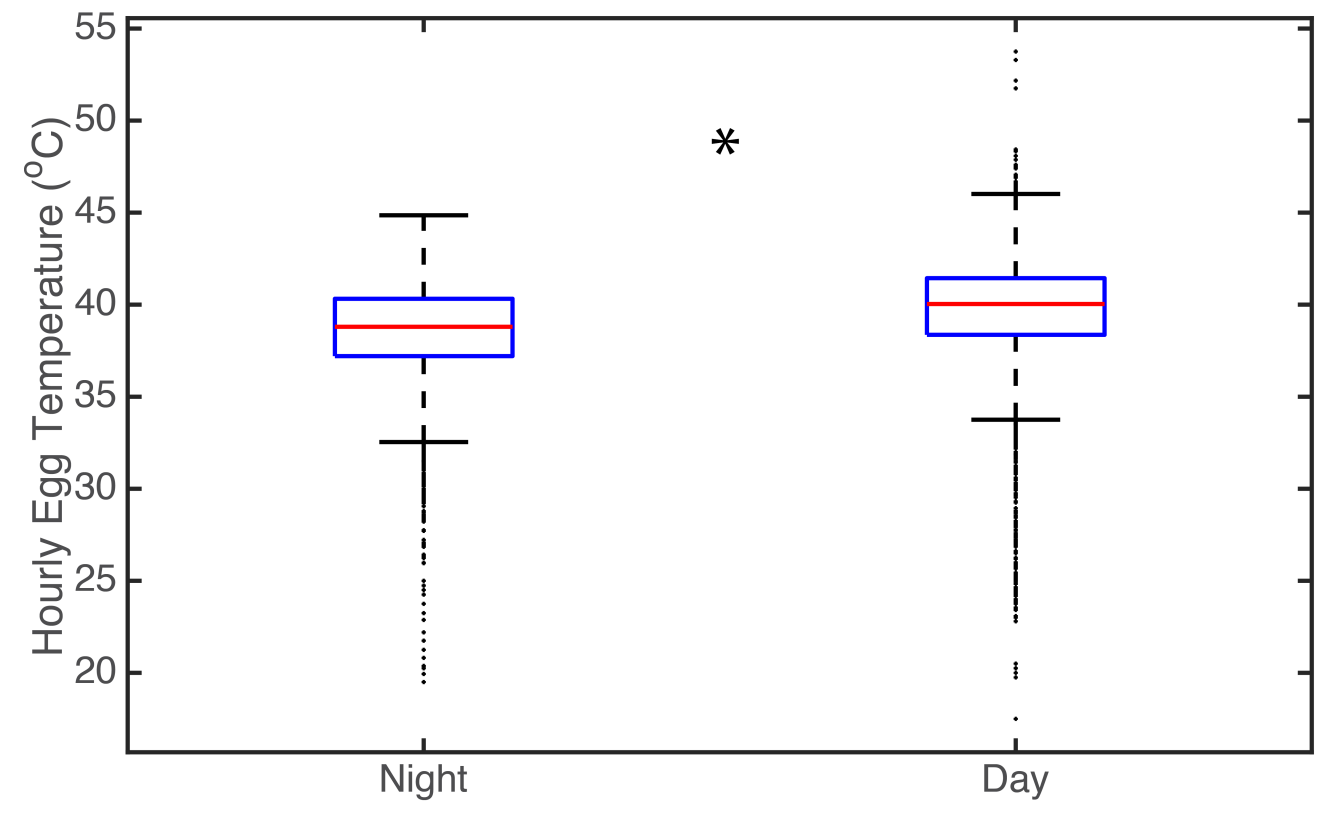

Figure 6. A boxplot showing the hourly egg temperature during the night and during the day in terns. The boxes denote the median, $25 \& 75 \%$ quartiles, the range of data, and outliers.

A second possible explanation for this diurnal fluctuation is the tendency for adults to leave their clutch unattended for a significant amount of time during the day, when ambient temperatures can become quite warm. Although air temperature was not 
measured at the colony sites, a NOAA buoy near colony R1 (NOAA, National Data Buoy Center, Station RTYC1) recorded air temperatures that increased in a linear manner from a mean of $13.1^{\circ} \mathrm{C}$ on 13 May 2015 to a mean of $19.4{ }^{\circ} \mathrm{C}$ on 9 July 2015 (LS linear regression, $\mathrm{p}<0.001, \mathrm{R}^{2}=0.342$; Figure 7). Egg temperature has a strong influence on determining the length of the incubation period (Boersma, 1982; Martin et al., 2007), and this may be especially critical for Forster's terns, which nest in marshes along the mainland and are thus more vulnerable than island-nesting seabirds to mammalian predators (Lack, 1968). A shorter incubation period would reduce the chances of egg depredation (Case, 1978; Martin et al., 2007), so the daytime periods of nest neglect, and associated increases in egg temperature, may therefore be adaptive. It would be interesting to determine the extent to which egg temperature affects the incubation period in this species, which can range between 23 and 26 days (Hall, 1989). In wood ducks (Aix sponsa), increases in incubation temperature have been shown to shorten the incubation period by as much as 3.3 days (Hepp et al., 2006).

Hourly daytime egg temperatures of Forster's terns were also significantly more variable than hourly nighttime egg temperatures. This difference in variability is likely due to the behavior of the parents, which exchange incubation duties several times during the day, mob predators, and often leave the nest unattended for a short period. At night, nests are attended more consistently, and both parents are often present (Bluso-Demers et al., 2010). The eggs of western gulls also exhibit increased temperature variability during the day, likely because this species is more active during the day (Shaffer et al., 2014), exchanging incubation duties and defending their nests from antagonistic neighbors 
(Pierotti, 1981). Seabirds that exhibit a lower frequency of turnover between adults during incubation (e.g. albatrosses), or that nest in cavities (e.g. auklets), do not exhibit such profound differences in egg temperature variability between day and night (Beaulieu et al., 2010b; Thierry et al., 2013a; Thierry et al., 2013b; Shaffer et al., 2014; Kelsey et al., 2016).

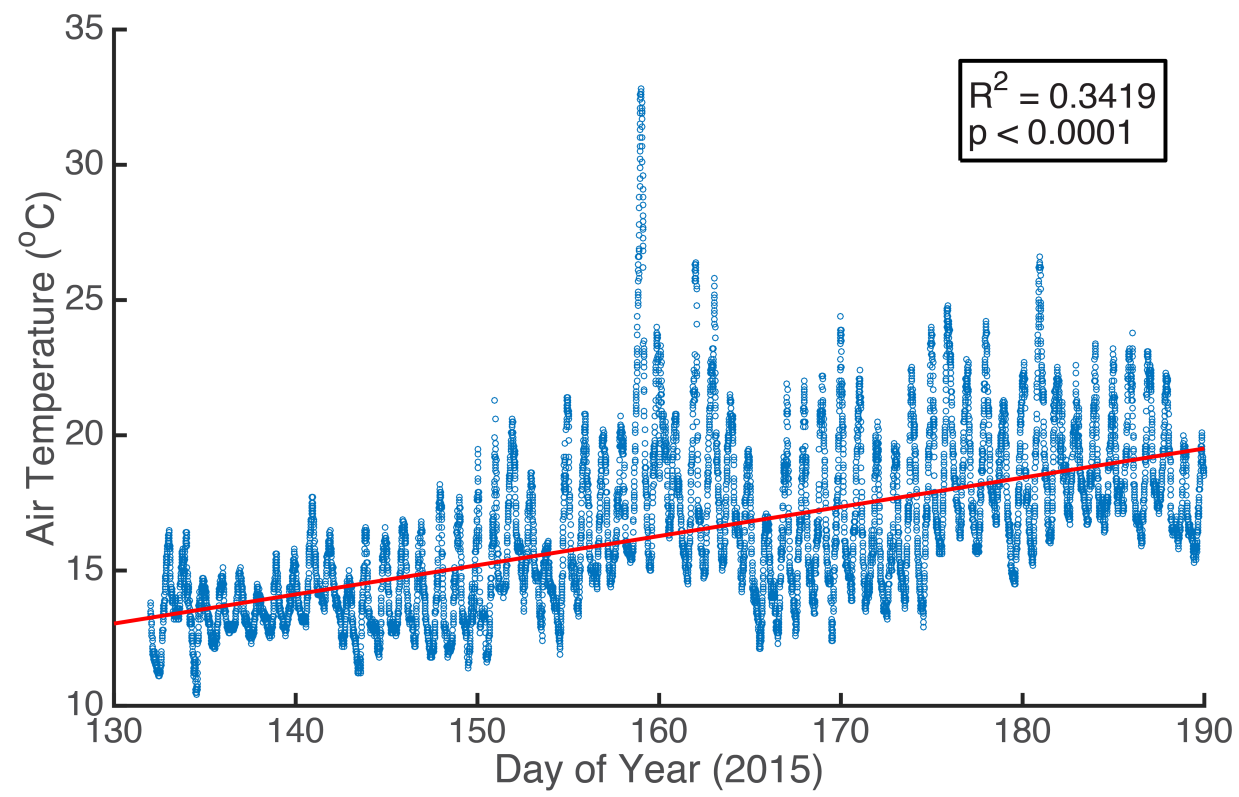

Figure 7. A scatterplot showing the air temperature recorded by NOAA buoy RTYC1, located near colony R1. Temperatures were recorded every 6 minutes between 13 May and 9 July 2015.

The difference in egg temperature between the mean maximum and mean minimum of Forster's terns was about $11^{\circ} \mathrm{C}$. While this is within the range of what has been found for other seabirds, it is higher than most (Webb, 1987; Shaffer et al., 2014). There are two likely explanations for the large temperature range experienced by tern eggs: 1) the behavior of the parents, and 2) environmental temperatures. Most seabirds cannot leave 
eggs unattended because the risk of predation is too great. Adélie penguins do, however, occasionally stand up in order to turn the eggs, preen, and respond to agonistic neighbors. It is during these brief bouts of standing that the eggs are exposed to the very low air temperatures and subsequently experience relatively sharp $\left(1-10^{\circ} \mathrm{C}\right)$ temperature declines (Derksen, 1977). Similarly, Forster's terns expose their eggs to both high and low environmental temperatures when they leave the nest momentarily to forage (BlusoDemers et al., 2010) or mob predators (Grant, 1982). Forster's tern embryos must tolerate especially strong diurnal fluctuations in environmental temperature because instead of nesting on oceanic islands or along coastlines like most seabirds, this species nests within marshes that can be quite distant from the stabilizing influence of the ocean.

Hourly egg temperature related positively to standardized nest initiation date, which may be related to environmental temperature. Nest initiation date ranged from 13 May to 9 July, and mean air temperature likely increased over the course of this time period (Figure 7). Another possible explanation is that less experienced adults breed later in the summer, and are less adept than more experienced adults at keeping their eggs adequately cool. More experienced Common terns (Sterna hirundo) arrive at their breeding colonies 19 days earlier than first-time breeders (Ludwigs and Becker, 2002).

Hourly egg temperature responded positively to hourly egg turning rate (Figure 8). This relationship is seen in Cassin's auklets (Kelsey et al., 2016), though egg temperature is negatively correlated with turning rate at night, when the parents are exchanging incubation duties. These auklets show no relationship between egg temperature and egg turning rate during the day, when the adult is sitting tight on the egg. The results for 
Forster's terns were similar. During the day, adult Forster's terns exchange incubation duties (Bluso-Demers et al., 2010), which exposes the eggs to more direct sunlight (and heat), possibly increasing egg temperature. These two species thus indicate that diurnal fluctuations in the parental exchange of incubation duties (and thus egg turning rate) may be associated with fluctuations in egg temperature. The small egg size of these two species -- approximately $27.5 \mathrm{~g}$ in Cassin's auklets (Manuwal, 1974) and $21.3 \mathrm{~g}$ in Forster's terns (McNicholl, 1971) -- likely plays a role in facilitating the effect of egg turning on egg temperature. Small eggs have a low thermal inertia, and thus will heat and cool more quickly than large eggs.

During nighttime, when the Forster's tern adults are sitting tight on their eggs, a different interpretation is needed to explain the positive relationship between egg temperature and egg turning: that egg turning ensures a more even distribution of heat across the egg. Embryonic circulation is capable of distributing warmth around the egg (Deeming, 2002). However, its capacity to do so is limited, as has been demonstrated in herring gulls where the temperature gradient across the egg ranges by as much as $12{ }^{\circ} \mathrm{C}$ at the onset of incubation to $4{ }^{\circ} \mathrm{C}$ near hatching (Drent, 1970). Thus egg turning as a mechanism to distribute heat energy across the egg may be critical during the second half of the incubation period, when the embryo is too large to float at the top of the egg near the brood patch (Drent, 1970). An even distribution of heat facilitated by egg turning likely plays a role in promoting continued development and growth of the embryo, though this has not yet been investigated in tern eggs. Studies on domestic fowl suggest another important function of even heat distribution around the egg: contact with the 
brood patch causes local reductions in blood vessel density in the chorio-allantoic membrane by as much as $40 \%$ (Ar and Reizes unpublished, cited in Deeming 2002). Notably, this occurred in the second half of the incubation period.

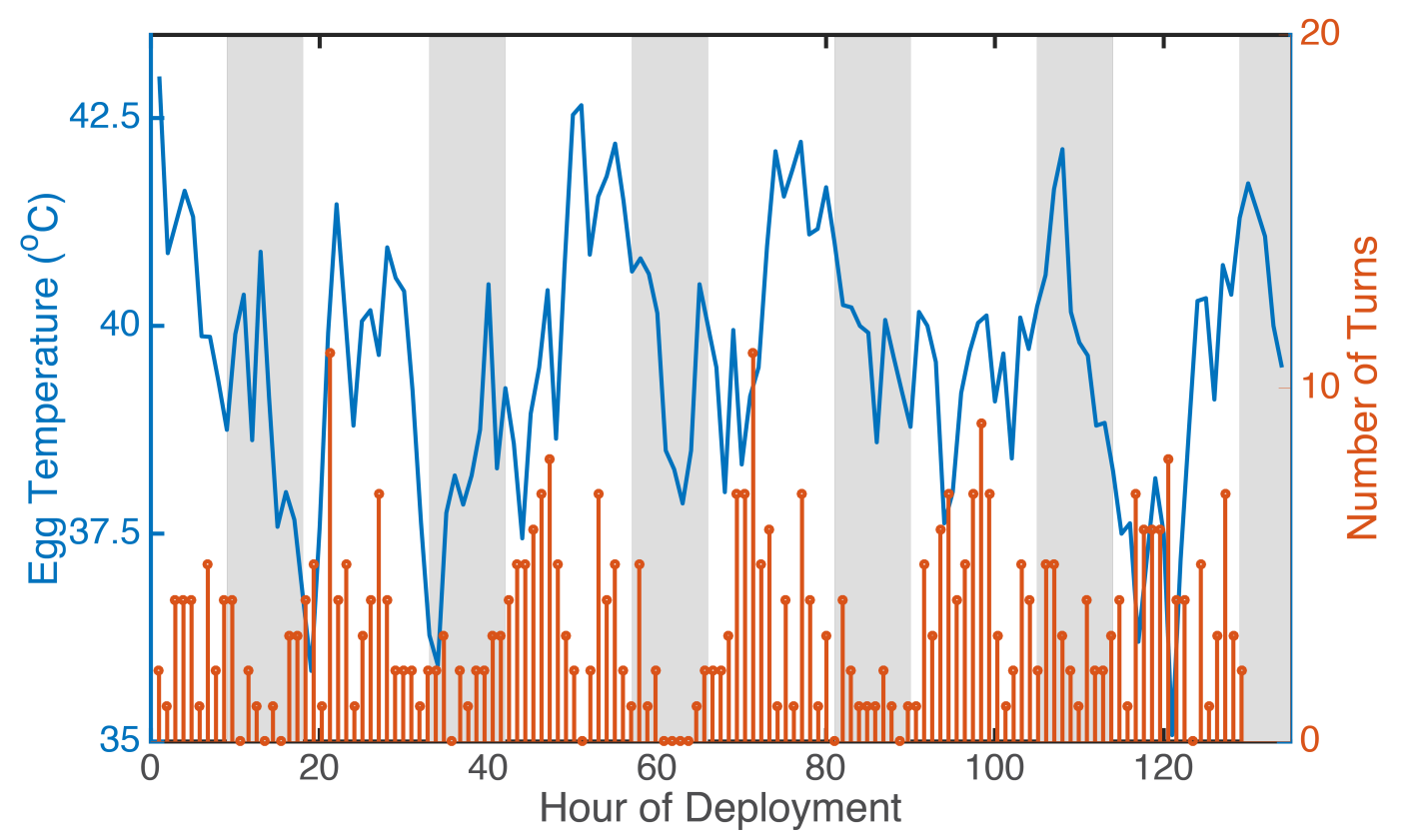

Figure 8. A mixed line/bar plot showing 5 days of egg temperature (blue line) and egg turn rate (orange bars) from a tern nest. White areas indicate daytime, while gray areas indicate nighttime.

If high daytime egg turning rate is a byproduct of adult foraging behavior and the associated exchanges of incubation duties, then egg turning during the night may be representative of the baseline amount of turning that is required for optimal embryonic development in Forster's terns. This could be tested by incubating eggs in an artificial incubator and maintaining a constant egg turning rate that mimics the Forster's tern's nighttime turning rate. The effect this has on hatchability could illuminate whether the elevated daytime egg turning rates that were observed in Forster's terns play a necessary 
role in embryonic development, or whether they serve some other function, such as shortening the incubation period and thereby reducing the risk of predation.

The results for Forster's terns contrast what has been found for western gulls and Laysan albatrosses, neither of which exhibit a relationship between egg temperature and egg turning rate (Shaffer et al., 2014). This could be due to a lack of diurnal fluctuations in the parental exchange of nest incubation duties in these species. The relationship between egg temperature and egg turning rate has not yet been examined in Adélie penguins, but because the adults do not exchange nest duties on a diurnal basis, it is likely that the two will not show a correlation.

\section{Application}

More than 200 currently threatened bird species would likely benefit from artificial incubation, and many of these species may be incapable of recovering without this method (Collar and Butchart, 2014). Artificial incubation plays a particularly important role in the recovery of the critically endangered New Zealand fairy tern (Sternula nereis davisae), a close relative of the Forster's tern, whose population has been severely impacted by introduced species (Hansen, 2006). The findings on the egg turning rate and egg temperature of Forster's terns could be used to improve the success of artificial incubation in such cases. Whether artificial incubation is effective for a particular species is largely determined by the egg turning rate and temperature of the incubator, two critical determinants of hatchability (Poulsen, 1953; Drent, 1975; Deeming, 1991; Deeming, 2002). The standard egg turning rate in an artificial incubator is 1 turn per hour, with a 45-degree rotation about the long axis (Deeming, 1991; Deeming, 2009). 
The amount of change in the pitch $\left(89.1 \pm 1.1\right.$ degrees $\left.\mathrm{h}^{-1}\right)$ that was observed in Forster's terns was particularly surprising, though whether it is a functional aspect of egg turning remains unclear. Artificial incubators generally do not control hourly changes in pitch, nor are such manipulations involved in poultry production (King'ori, 2011). The findings also indicate that taxonomic order is not always a useful predictor of egg turning rate, as can be seen in the different egg turning rates of western gulls and Forster's terns, both Charadriiformes. Instead, albumen content of the egg may be a better predictor, as suggested by Deeming (2002). In addition to egg turning rate, the findings on egg temperature show that the typical artificial incubator may not be suitable for some species. Incubators typically operate at $37-38^{\circ} \mathrm{C}$, which has been found to be the optimum for galliform eggs (Deeming and Jarrett, 2015), but which largely falls below the egg temperatures that were recorded for Forster's terns. The results show that studying the natural incubation behavior of wild birds may help to increase the effectiveness of conservation measures such as artificial incubation.

\section{Future Directions}

Future research could investigate (1) variation in egg turning rate over the course of the entire incubation period in seabirds; (2) the influence of behaviors such as foraging, mobbing, and "dipping" on egg turning rate; (3) the relative importance of roll, pitch, and yaw in egg turning events of taxa with large clutch sizes, such as the Anseriformes; (4) differences in egg turning rate and egg temperature between adults of different experience levels; (5) the extent to which increased egg temperature can shorten the duration of the incubation period in Forster's terns and thereby lower the risk of 
predation; and (6) the potential effects of mercury on incubation behavior at the beginning of the incubation period. 


\section{Literature Cited}

Accurso, L.M. (1992). Distribution and Abundance of Wintering Waterfowl on San Francisco Bay, 1988-1990. M.S. thesis, Humboldt State University, Arcata, CA.

Ackerman, J. T., \& Eagles-Smith, C. A. (2009). Integrating toxicity risk in bird eggs and chicks: using chick down feathers to estimate mercury concentrations in eggs. Environmental Science \& Technology, 43, 2166-2172.

Ackerman, J. T., \& Eagles-Smith, C. A. (2010). Accuracy of egg flotation throughout incubation to determine embryo age and incubation day in waterbird nests. Condor, $112,438-446$.

Ackerman, J. T., Eagles - Smith, C. A., Takekawa, J. Y., Bluso, J. D., \& Adelsbach, T. L. (2008a). Mercury concentrations in blood and feathers of prebreeding Forster's terns in relation to space use of San Francisco Bay, California, USA, habitats. Environmental Toxicology and Chemistry, 27, 897-908.

Ackerman, J. T., Takekawa, J. Y., Eagles-Smith, C. A., \& Iverson, S. A. (2008b). Mercury contamination and effects on survival of American avocet and black-necked stilt chicks in San Francisco Bay. Ecotoxicology, 17, 103-116.

Ackerman, J. T., Herzog, M. P., \& Schwarzbach, S. E. (2013). Methylmercury is the predominant form of mercury in bird eggs: a synthesis. Environmental Science \& Technology, 47, 2052-2060.

Ackerman, J. T., Eagles-Smith, C. A., Heinz, G., De La Cruz, S. G., Takekawa, J. Y., Miles, A. K., \& Maurer, T. C. (2014). Mercury in birds of San Francisco Bay-Delta, California - Trophic pathways, bioaccumulation, and ecotoxicological risk to avian reproduction: U.S. Geological Survey Open-File Report 2014-1251, 202 p.

Ackerman, J. T., Eagles-Smith, C. A., Herzog, M. P., \& Hartman, C. A. (2016). Maternal transfer of contaminants in birds: mercury and selenium concentrations in parents and their eggs. Environmental Pollution, 210, 145-154.

Ainley, D. (2002). The Adélie Penguin: Bellwether of Climate Change. New York: Columbia University Press.

Angelier, F., \& Chastel, O. (2009). Stress, prolactin and parental investment in birds: a review. General and Comparative Endocrinology, 163, 142-148.

Astheimer, L. B. (1986). Egg formation in Cassin's Auklet. Auk, 103, 682-693. 
Astheimer, L. B., \& Grau, C. R. (1985). The timing and energetic consequences of egg formation in the Adélie penguin. Condor, 87, 256-268.

Ball, G. F. (1991). Endocrine mechanisms and the evolution of avian parental care. Acta XX Congressus Internationalis Ornithologici, 20, 984-991.

Beaulieu, M., Dervaux, A., Thierry, A. M., Lazin, D., Le Maho, Y., Ropert - Coudert, Y., Spee, M., Raclot, T., \& Ancel, A. (2010a). When sea - ice clock is ahead of Adélie penguins' clock. Functional Ecology, 24, 93-102.

Beaulieu, M., Thierry, A. M., Handrich, Y., Massemin, S., Le Maho, Y., \& Ancel, A. (2010b). Adverse effects of instrumentation in incubating Adélie penguins (Pygoscelis adeliae). Polar Biology, 33, 485-492.

Beer, C. G. (1961). Incubation and nest building behaviour of Black-headed Gulls. I: Incubation behaviour in the incubation period. Behaviour, 18, 62-105.

Bergman, R. D., Swain, P., \& Weller, M. W. (1970). A comparative study of nesting Forster's and Black Terns. The Wilson Bulletin, 82, 435-444.

Bluso-Demers, J., Colwell, M. A., Takekawa, J. Y., \& Ackerman, J. T. (2008). Space use by Forster's Terns breeding in south San Francisco Bay. Waterbirds, 31, 357-369.

Bluso-Demers, J. D., Ackerman, J. T., \& Takekawa, J. Y. (2010). Colony attendance patterns by mated Forster's Terns Sterna forsteri using an automated data-logging receiver system. Ardea, 98, 59-65.

Boersma, P. D. (1982). Why some birds take so long to hatch. American Naturalist, 120, 733-750.

Boulton, R. L., \& Cassey, P. (2012). How avian incubation behaviour influences egg surface temperatures: relationships with egg position, development and clutch size. Journal of avian biology, 43, 289-296.

Byerly, T. C. (1938). Effect of different incubation temperatures on mortality of chick embryos. Poultry Science, 17, 200-205.

Caldwell, P. J., \& Cornwell, G. W. (1975). Incubation behavior and temperatures of the mallard duck. Auk, 92, 706-731.

Card, L. E. (1926). Incubator eggs turned first six days hatch well. Reports of the Illinois Agricultural Experiment Station, 39, 78.

Carey, C. (1980). The ecology of avian incubation. BioScience, 30, 819-824. 
Carvalho, M. C., Nazari, E. M., Farina, M., \& Muller, Y. M. (2008). Behavioral, morphological, and biochemical changes after in ovo exposure to methylmercury in chicks. Toxicological Sciences, 106, 180-185.

Case, T. J. (1978). On the evolution and adaptive significance of postnatal growth rates in the terrestrial vertebrates. Quarterly Review of Biology, 53, 243-282.

Clatterbuck, C. (2014). Do Parents Rock and Roll All Night? Temporal Egg Turning Behavior In Long-Lived Seabirds. M.S. thesis, San Jose State University, San Jose, CA.

Collar, N. J., \& Butchart, S. H. M. (2014). Conservation breeding and avian diversity: chances and challenges. International Zoo Yearbook, 48, 7-28.

Deeming, D. C. (1989). Characteristics of unturned eggs: critical period, retarded embryonic growth and poor albumen utilisation. British Poultry Science, 30, 239-249.

Deeming, D. C. (1991). Reasons for the dichotomy in egg turning in birds and reptiles. In: Deeming D.C. and Ferguson W.J., (eds.), Egg Incubation: Its Effects on Embryonic Development in Birds and Reptile 307-323. Cambridge: Cambridge University Press.

Deeming, D. C. (2002a). Avian Incubation: Behaviour, Environment and Evolution. Oxford: Oxford University Press.

Deeming, D. C. (2002b). Patterns and significance of egg turning. In: D. C. Deeming, (ed.), Avian Incubation: Behaviour, Environment, and Evolution 161-178. New York: Oxford University Press.

Deeming, D. C. (2009). The role of egg turning during incubation. Avian Biology Research, 2, 67.

Deeming, D. C., \& Ferguson, M. W. (1991). Egg incubation: its effects on embryonic development in birds and reptiles. Cambridge: Cambridge University Press.

Deeming, D.C. \& Jarrett, N.S. (2015). Applications of incubation science to aviculture and conservation. In: Deeming, D.C. \& Reynolds, S.J., (eds.), Nests, Eggs and Incubation: New Ideas About Avian Reproduction 196-207. Oxford: Oxford University Press.

Derksen, D. V. (1977). A quantitative analysis of the incubation behavior of the Adelie Penguin. Auk, 94, 552-566. 
Dinsmore, J. J. (1970). Sooty tern behavior. Doctoral dissertation, University of Florida, Gainesville, FL.

Drent, R. H. (1970). Functional aspects of incubation in the Herring Gull. Behaviour. Supplement, 17, 1-132.

Drent, R. (1975). Incubation. Avian biology, 5, 333-420.

Eagles-Smith, C. A., \& Ackerman, J. T. (2010). Developing Impairment Thresholds for the Effects of Mercury on Forster's Tern Reproduction in San Francisco Bay. Data Summary, U. S. Geological Survey, Western Ecological Research Center, Davis, CA. $21 \mathrm{p}$.

Eagles-Smith, C. A., Ackerman, J. T., De La Cruz, S. E., \& Takekawa, J. Y. (2009). Mercury bioaccumulation and risk to three waterbird foraging guilds is influenced by foraging ecology and breeding stage. Environmental Pollution, 157, 1993-2002.

Elibol, O., \& Brake, J. (2004). Identification of critical periods for turning broiler hatching eggs during incubation. British Poultry Science, 45, 631-637.

EPA, U. (2000). Mercury in solids and solutions by thermal decomposition, amalgamation, and atomic absorption spectrophotometry; Washington, DC.

Evers, D. C., Lane, O. P., Savoy, L., \& Goodale, W. (2004). Assessing the impacts of methylmercury on piscivorous wildlife using a wildlife criterion value based on the common loon, 1998-2003. Unpubl. report BRI 2004-05 submitted to the Maine Department of Environmental Protection. BioDiversity Research Institute, Gorham, ME.

Evers, D. C., Savoy, L. J., DeSorbo, C. R., Yates, D. E., Hanson, W., Taylor, K. M., Siegel, L. S., Cooley Jr., J. H., Bank, M. S., Major, A., Munney, K., Mower, B. $\quad$ F., Vogel, H. F., Schoch, N., Pokras, M., Goodale, M. W., \& Fair, J. (2008). Adverse effects from environmental mercury loads on breeding common loons. Ecotoxicology, $17,69-81$.

Fraser, G. (1997). Feeding ecology of Forster's Terns on Lake Osakis, Minnesota. Colonial Waterbirds, 20, 87-94.

French, N. A. (1994). Effect of incubation temperature on the gross pathology of turkey embryos. British Poultry Science, 35, 363-371.

French, N. A. (2000). Effect of short periods of high incubation temperature on hatchability and incidence of embryo pathology of turkey eggs. British Poultry Science, 41, 377-382. 
Funk, E. M., \& Forward, J. F. (1953). The effect of angle of turning eggs during incubation on hatchability. Reseach Bulletin, Missouri Agricultural Experiment Station, 502. University of Missouri, Columbia.

Funk, E. M., \& Forward, J. F. (1960). The relation of angle of turning and position of the egg to hatchability of chicken eggs. Poultry Science, 39, 784-785.

Goldsmith, A. R. (1991). Prolactin and avian reproductive strategies. In: Acta XX Congressus Internationalis Ornithologici 2063-2071. Wellington, New Zealand: New Zealand Ornithological Congress Trust Board.

Grant, G. S. (1982). Avian incubation: egg temperature, nest humidity, and behavioral thermoregulation in a hot environment. Ornithological Monographs, 30, iii-75.

Hall, J. A. (1989). Aspects of Forster's Tern (Sterna forsteri) Reproduction on Cobblestone lslands in Southcentral Washington. Northwest Science, 63, 90-95.

Hamburger, V., \& Oppenheim, R. (1967). Prehatching motility and hatching behavior in the chick. Journal of Experimental Zoology, 166, 171-203.

Hansen, K. (2006). New Zealand fairy tern (Sterna nereis davisae) recovery plan, 200515. Threatened Species Recovery Plan 57. Department of Conservation, Wellington. $32 \mathrm{p}$.

Heath, J. A., \& Frederick, P. C. (2005). Relationships among mercury concentrations, hormones, and nesting effort of white ibises (Eudocimus albus) in the Florida Everglades. Auk, 122, 255-267.

Hepp, G. R., Kennamer, R. A., \& Johnson, M. H. (2006). Maternal effects in wood ducks: incubation temperature influences incubation period and neonate phenotype. Functional Ecology, 20, 308-314.

Herring, G., Ackerman, J. T., \& Eagles - Smith, C. A. (2010). Embryo malposition as a potential mechanism for mercury - induced hatching failure in bird eggs.

Environmental Toxicology and Chemistry, 29, 1788-1794.

Herring, G., Ackerman, J. T., \& Herzog, M. P. (2012). Mercury exposure may suppress baseline corticosterone levels in juvenile birds. Environmental Science \& Technology, $46,6339-6346$.

Herzog, M. P., Ackerman, J. T., Eagles-Smith, C. A., \& Hartman, C. A. (2016). It's what's inside that counts: egg contaminant concentrations are influenced by estimates of egg density, egg volume, and fresh egg mass. Ecotoxicology, 25, 770-776. 
Hoffman, D. J. (1990). Embryotoxicity and teratoge- nicity of environmental contaminants to bird eggs. Review of Environmental Contamants and Toxicology, $115,40-89$.

Howell, T. R., \& Bartholomew, G. A. (1961a). Temperature regulation in Laysan and Black-footed Albatrosses. Condor, 63, 185-197.

Howell, T. R., \& Bartholomew, G. A. (1961b). Temperature regulation in nesting Bonin Island petrels, wedge-tailed shearwaters, and Christmas Island shearwaters. Auk, 78, 343-354.

Howell, T. R., \& Bartholomew, G. A. (1962a). Temperature regulation in the Red-tailed Tropic Bird and the Red-footed Booby. Condor, 64, 6-18.

Howell, T. R., \& Bartholomew, G. A. (1962b). Temperature regulation in the Sooty Tern Sterna fuscata. Ibis, 104, 98-105.

Howey, P., Board, R. G., Davis, D. H., \& Kear, J. (1984). The microclimate of the nests of waterfowl. Ibis, 126, 16-32.

Hutt, F. B., \& Pilkey, A. M. (1930). Studies in Embryonic Mortality in the Fowl IV: Comparative Mortality Rates in Eggs Laid at Different Periods of the Day and their Bearing on Theories of the Origin of Monsters. Poultry Science, 9, 194-203.

Jayasena, N. (2010). Effects of chronic methylmercury exposure on reproductive success, behavior, and steroid hormones of the white ibis (Eudocimus albus). Doctoral dissertation, University of Florida, Gainesville, FL.

Kasielke S. (2007). Incubation of Eggs. In: Gage, L. J. and Duerr, R. S. (eds.) HandRearing Birds 39-54. Ames, Iowa: Blackwell Publishing.

Kelsey, E. C., Bradley, R. W., Warzybok, P., Jahncke, J., \& Shaffer, S. A. (2016). Environmental temperatures, artificial nests, and incubation of Cassin's auklet. The Journal of Wildlife Management, 80, 292-299.

King'Ori, A. M. (2011). Review of the factors that influence egg fertility and hatchability in poultry. International Journal of Poultry Science, 10, 483-492.

Lack, D. L. (1968). Ecological adaptations for breeding in birds. London: Methuen.

Love, O. P., Breuner, C. W., Vézina, F., \& Williams, T. D. (2004). Mediation of a corticosterone-induced reproductive conflict. Hormones and Behavior, 46, 59-65. 
Ludwigs, J. D., \& Becker, P. H. (2002). The hurdle of recruitment: influences of arrival date, colony experience and sex in the common tern Sterna hirundo. Ardea, 90, 389399.

Manuwal, D. A. (1974). The natural history of Cassin's Auklet (Ptychoramphus aleuticus). Condor, 76, 421-431.

Martin, T. E., Auer, S. K., Bassar, R. D., Niklison, A. M., \& Lloyd, P. (2007). Geographic variation in avian incubation periods and parental influences on embryonic temperature. Evolution, 61, 2558-2569.

Marvin-DiPasquale, M., Agee, J., Bouse, R., \& Jaffe, B. (2003). Microbial cycling of mercury in contaminated pelagic and wetland sediments of San Pablo Bay, California. Environmental Geology, 43, 260-267.

McNicholl, M. K. (1971). The breeding biology and ecology of Forster's Tern (Sterna forsteri) at Delta, Manitoba. M.S. Thesis, University of Manitoba, Winnipeg.

Meathrel, C. E., Ryder, J. P., \& Termaat, B. M. (1987). Size and composition of Herring Gull eggs: relationship to position in the laying sequence and the body condition of $\mathrm{f}$ emales. Colonial Waterbirds, 10, 55-63.

Molenaar, R., Meijerhof, R., Van den Anker, I., Heetkamp, M. J. W., Van den Borne, J. J. G. C., Kemp, B., \& Van Den Brand, H. (2010). Effect of eggshell temperature and oxygen concentration on survival rate and nutrient utilization in chicken embryos. Poultry Science, 89, 2010-2021.

Moore, C. S., Cristol, D. A., Maddux, S. L., Varian-Ramos, C. W., \& Bradley, E. L. (2014). Lifelong exposure to methylmercury disrupts stress - induced corticosterone response in zebra finches (Taeniopygia guttata). Environmental Toxicology and Chemistry, 33, 1072-1076.

New, D. A. T. (1957). A critical period for the turning of hens' eggs. Development, 5, 293-299.

Nisbet, I. C. T. (1978). Dependence of fledging success on egg-size, parental performance and egg-composition among common and roseate terns, Sterna hirundo and S. dougallii. Ibis, 120, 207-215.

Page, G. W., Stenzel, L. E., \& Kjelmyr, J. E. (1999). Overview of shorebird abundance and distribution in wetlands of the Pacific Coast of the contiguous United States. Condor, 101, 461-471. 
Pierotti, R. (1981). Male and female parental roles in the Western Gull under different environmental conditions. Auk, 98, 532-549.

Poulsen, H. (1953). A study of incubation responses and some other behaviour patterns in birds. Videnskabelige Meddelelser Dansk Naturhistorisk Forening, 115, 1-131.

Pulliainen, E. (1978). Behaviour of a Willow Grouse Lagopus l. lagopus at the nest. Ornis Fenn, 55, 141-148.

Ramsar, I. (1971). Convention on Wetlands of International Importance, Especially as Waterfowl Habitat. Ramsar (Iran).

Rice, D. W., \& Kenyon, K. W. (1962). Breeding cycles and behavior of Laysan and Black-footed Albatrosses. Auk, 79, 517-567.

Robertson, I. S. (1961). The influence of turning on the hatchability of hens' eggs II. The effect of turning frequency on the pattern of mortality, the incidence of malpositions, malformations and dead embryos with no somatic abnormality. The Journal of Agricultural Science, 57, 57-69.

Scheuhammer, A. M. (1987). The chronic toxicity of aluminium, cadmium, mercury, and lead in birds: a review. Environmental Pollution, 46, 263-295.

Schreiber, R. W. (1970). Breeding biology of western gulls (Larus occidentalis) on San Nicolas Island, California, 1968. Condor, 72, 133-140.

Shaffer, S. A, C. A. Clatterbuck, E. K. Kelsey, A. Naiman, L. Young, E. VanderWerf, P. M. Warzybok, R. W. Bradley, J. Jahncke, \& Bower, G. C. (2014). As the egg turns: monitoring egg attendance behavior in wild birds using novel data logging technology. PLoS ONE, 9, e97898.

Stenzel, L. E., Hickey, C. M., Kjelmyr, J. E., \& Page, G. W. (2002). Abundance and distribution of shorebirds in the San Francisco Bay area. Western Birds, 33, 69-98.

Takeshita, K., \& McDaniel, G. R. (1982). Relationship of egg position during incubation on early embryonic growth and hatching of broiler breeder eggs. Poultry Science, 61, 667-672.

Tartu, S., Goutte, A., Bustamante, P., Angelier, F., Moe, B., Clément-Chastel, C. \& Chastel, O. (2013). To breed or not to breed: endocrine response to mercury contamination by an Arctic seabird. Biology Letters, 9, 20130317.

Tartu, S., Angelier, F., Wingfield, J.C., Bustamante, P., Labadie, P., Budzinski, H., Weimerskirch, H., Bustnes, J.O., \& Chastel, O. (2015). Corticosterone, prolactin and 
egg neglect behavior in relation to mercury and legacy POPs in a long-lived Antarctic bird. Science of the Total Environment, 505, 180-188.

Thaxton, J. P., Gilbert, J., Hester, P. Y., \& Brake, J. (1982). Mercury toxicity as compared to adrenocorticotropin-induced physiological stress in the chicken. Archives of Environmental Contamination and Toxicology, 11, 509-514.

Thierry, A. M., Brajon, S., Massemin, S., Handrich, Y., Chastel, O., \& Raclot, T. (2013a). Decreased prolactin levels reduce parental commitment, egg temperatures, and breeding success of incubating male Adélie penguins. Hormones and Behavior, $64,737-747$.

Thierry, A. M., Massemin, S., Handrich, Y., \& Raclot, T. (2013b). Elevated corticosterone levels and severe weather conditions decrease parental investment of incubating Adélie penguins. Hormones and Behavior, 63, 475-483.

Tona, K., Onagbesan, O., Bruggeman, V., Mertens, K., \& Decuypere, E. (2005). Effects of turning duration during incubation on embryo growth, utilization of albumen, and stress regulation. Poultry Science, 84, 315-320.

Tullett, S. G., \& Deeming, D. C. (1987). Failure to turn eggs during incubation: effects on embryo weight, development of the chorioallantois and absorption of albumen. British Poultry Science, 28, 239-243.

Valanne, K. (1966). Incubation behaviour and temperature of capercaillie (Tetrao urogallus) and Willow Grouse (Lagopus lagopus). Suomen Riista, 19, 30-41.

Van Roo, B. L., Ketterson, E. D., \& Sharp, P. J. (2003). Testosterone and prolactin in two songbirds that differ in paternal care: the blue-headed vireo and the red-eyed vireo. Hormones and Behavior, 44, 435-441.

Vleck, C.M., (1998). Hormonal control of incubation/brooding behavior: lessons from Wild birds. In: Proceedings of the WSPA 10 European Poultry Conference, Israel, 1998, p. 163-169.

Vleck, C. M. (2002). Hormonal control of incubation behaviour. Oxford Ornithology Series, 13, 54-62.

Warham, J. (1983). The composition of petrel eggs. Condor, 85, 194-199.

Weaver, R. L., \& West, F. H. (1943). Notes on the breeding of the Pine Siskin. Auk, 60, 492-504. 
Webb, D. R. (1987). Thermal tolerance of avian embryos: a review. Condor, 89, 874898.

Weller, M. W. (1961). Breeding biology of the Least Bittern. The Wilson Bulletin, 73, 1135.

Westerskov, K. (1950). Methods for determining the age of game bird eggs. The Journal of Wildlife Management, 14, 56-67.

Wilson, H. R., Neuman, S. L., Eldred, A. R., \& Mather, F. B. (2003). Embryonic malpositions in broiler chickens and bobwhite quail. The Journal of Applied Poultry Research, 12, 14-23.

Zar, J. H. (1999). Biostatistical analysis, $4^{\text {th }}$ edition. Prentice-Hall, Upper Saddle River, NJ. 